\title{
EFFECTS OF AEROBIC TRAINING ON THE CARDIOMYOCYTES OF THE RIGHT ATRIUM OF MICE
}

\author{
EFEITOS DO TREINAMENTO AERÓBICO EM CARDIOMIÓCITOS DO ÁTRIO DIREITO DE CAMUNDONGOS
}

EFECTOS DEL ENTRENAMIENTO AERÓBICO EN CARDIOMIOCITOS DEL ATRIO DERECHO DE RATONES

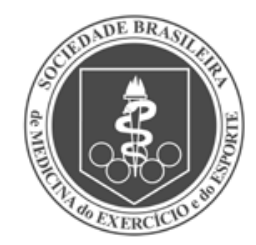

Original Article

Artigo Original Artículo Original
Vanessa Gonçalves Coutinho de Oliveira' (Physiotherapist)

Laura Beatriz Mesiano Maifrino' (Biomedicine)

Tania Cristina Pithon-Curi² (Physical Educator)

Elias de França' (Physical Educator)

Romeu Rodrigues de Souza ${ }^{3}$ (Physician)

1. Universidade São Judas Tadeu, São Paulo, SP, Brazil.

2. Universidade Cruzeiro do Sul, São Paulo, SP, Brazil.

3. Universidade de São Paulo, São Paulo, SP, Brazil.

\section{Correspondência:}

Romeu Rodrigues de Souza. São Judas Tadeu University, 546, Taquari, Moóca, São Paulo, SP, Brazil. 03166-000.

souzarrd@uol.com.br

\begin{abstract}
Introduction: Polypeptide hormones (natriuretic peptides, NPs) are secreted by the cardiac atria and play an important role in the regulation of blood pressure. Objective: To evaluate the effects of aerobic training on the secretory apparatus of NPs in cardiomyocytes of the right atrium. Methods: Nine-month-old mice were divided in two groups ( $n=10$ ): control group (CG) and trained group (TG). The training protocol was performed on a motor treadmill for 8 weeks. Systolic blood pressure was measured at the beginning of the experiment (9 months of age) and at moment of the sacrifice (11 months of age). Electron micrographs were used to quantify the following variables: the quantitative density and area of NP granules, the relative volumes of the mitochondria, endoplasmic reticulum, and Golgi complex and the relative volume of euchromatin in the nucleus and the number of pores per $10 \mu \mathrm{m}$ of the nuclear membrane. The results were compared by Student's t test $(p<0.05)$. Results: The cardiomyocytes obtained from TG mice showed increased density and sectional area of secretory granules of NP, higher relative volume of endoplasmic reticulum, mitochondria, and Golgi complex compared with the CG mice. Furthermore, the quantitative density of nuclear pores and the relative volume of euchromatin in the nucleus were significantly higher compared with the CG mice. Conclusion: Aerobic training caused hypertrophy of the secretory apparatus in the cardiomyocytes of right atrium, which could explain the intense synthesis of natriuretic peptides in trained mice with respect to the untrained mice.
\end{abstract}

Keywords: secretory vesicles; myocytes, cardiac; natriuretic peptide, brain; exercise therapy; microscopy, electron.

\section{RESUMO}

Introdução: Os hormônios polipeptídicos (peptídeos natriuréticos, PN) são secretados pelos átrios cardíacos e desempenham um papel importante na regulação da pressão arterial. Objetivo: Avaliar os efeitos do treinamento aeróbico sobre o aparelho secretor de PN nos cardiomiócitos do átrio direito. Métodos: Camundongos com nove meses de idade foram divididos em dois grupos ( $n=10)$ : grupo controle (GC) e grupo treinado (GT). O protocolo de treinamento foi realizado em esteira motorizada durante 8 semanas. A pressão sistólica dos animais foi medida no início do experimento (9 meses de idade) e no momento do sacrifício (11 meses). Foram usadas eletromicrografias para quantificar as seguintes variáveis densidade quantitativa e área dos grânulos de PN; volumes relativos (\%) de mitocôndrias, retículo endoplasmático e aparelho de Golgi e o volume relativo de eucromatina no núcleo e o número de poros por $10 \mu \mathrm{m}$ de membrana nuclear. Os resultados foram comparados pelo teste t de Student $(p<0,05)$. Resultados: Os cardiomiócitos obtidos dos camundongos GT apresentaram maior densidade e área seccional de grânulos secretórios de PN, aumento do volume relativo do retículo endoplasmático, das mitocôndrias e do complexo de Golgi, em comparação com os camundongos GC. Além disso, a densidade quantitativa dos poros nucleares eo volume relativo da eucromatin a nuclear foram significantemente superiores em comparação com os camundongos GC. Conclusão: O treinamento aeróbico causou hipertrofia do aparelho secretor dos cardiomiócitos do átrio direito, o que poderia explicar a síntese intensa de peptídeos natriuréticos em camundongos treinados, quando comparados aos não treinados.

Descritores: vesículas secretórias; miócitos cardíacos; peptídeo natriurético encefálico; terapia por exercício; microscopia eletrônica.

\section{RESUMEN}

Introducción: Las hormonas polipeptídicas (péptidos natriuréticos, PN) son secretadas por las aurículas cardiacas y juegan un papel importanteen la regulación de la presión arterial. Objetivo: Evaluar los efectos del entrenamiento aeróbico sobre el aparato secretor de PN en cardiomiocitos de la aurícula derecha. Métodos: Ratones de nueve meses de edad fueron divididos en dos grupos ( $n=10)$ : grupo control (GC) y grupo entrenado (GE). El protocolo de entrenamiento se realizó en cinta caminadora durante 8 semanas. La presión arterial sistólica se midió al inicio del experimento (9 meses de edad) y en el momento del sacrificio (11 meses de edad). Las electromicrografías se utilizaron para cuantificar las siguientes variables: I densidad cuantitativa y el área de gránulos de PN; los volúmenes relativos (\%) de mitocondrias, del retículo endoplásmico y del aparato de Golgi y el volumen relativo de eucromatina en el núcleo y el número de poros por $10 \mu \mathrm{m}$ de la membrana nuclear. Los resultados se compararon mediante la prueba t de Student $(p<0,05)$. Resultados: Los cardiomiocitos obtenidos de los ratones GE mostraron aumento de la densidad y del área seccional de gránulos secretorios 
de PN, aumento del volumen relativo de retículo endoplásmico, mitocondrias y aparato de Golgi en comparación con los ratones GC. Además, la densidad cuantitativa de los poros nucleares y el volumen relativo de la eucromatina nuclear fueron significativamente mayores en comparación con los ratones CG. Conclusión: El entrenamiento aeróbico causó hipertrofia del aparato secretor en los cardiomiocitos de la aurícula derecha, lo que podría explicar la intensa síntesis de péptidos natriuréticos en ratones entrenados con respecto a los ratones no entrenados.

Descriptores: vesículas secretoras; miocitos cardíacos; péptido natriurético encefálico; terapia por ejercicio; microscopía electrónica.

\section{INTRODUCTION}

Natriuretic peptides (NPs) are hormones synthesized and stored in atrial cardiomyocytes being secreted into the bloodstream for the regulation of blood pressure (BP) 1 . Studies have shown that specific atrium granules contain NP pro hormones ${ }^{2}$. The production and secretion of NPs depend on the structural components of the atrium cardiomyocytes including the Golgi apparatus, mitochondria, endoplasmic reticulum, the euchromatin and the number of pores in the nuclear membrane ${ }^{3}$.

It is well known that during aerobic exercise blood pressure rises ${ }^{4}$ which causes an increase in the secretion of NPs in the bloodstream ${ }^{5-7}$, contributing for the acute control of hypertension, promoted by exercise. However, to the best of our knowledge, no studies in the literature have examined the relationship between aerobic training, arterial pressure and the secretory apparatus of NPs in mice.

The objective of the present study was to extend previous findings in two important ways. First, aerobic training can have a significant influence on BP and there is a direct relationship between BP and the NP system in experimental animals $\mathrm{s}^{6-10}$. However, there are no observations of NP system, were aerobic-trained mice were compared with sedentary controls. The first objective of this study was to observe the effects of aerobic training on the number and sizes of NP granules. The second objective of this work was to evaluate the quantitative effects of aerobic training on the secretory apparatus of the atrium cardiomyocytes, including the number of pores per $10 \mu \mathrm{m}$ of nuclear membrane, the relative volumes (\%) of euchromatin, mitochondria, endoplasmic reticulum and Golgi complex in the cardiomyocytes of the trained mice compared with sedentary controls. We hipothesize that aerobic training could cause hypertrophy of the secretory apparatus in cardiomyocytes and influence the synthesis of NPs.

\section{MATERIALS AND METHODS}

Experiments were performed on nine-month-age male C57BL mice (25-30 g) from the Animal Care Facility of the Universidade São Judas Tadeu (São Paulo, Brazil). The animals received standard laboratory chow and water ad libitum. They were housed in individual cages in a temperature-controlled room $\left(22^{\circ} \mathrm{C}\right)$ with a 12-hour dark/light cycle. All mice were treated similarly in terms of daily manipulation. All surgical procedures and protocols used were approved by the Experimental Animal Use Committee of the Universidade São Judas Tadeu (Ethical Protocol Number A003/2010) and were conducted in accordance with National Institute of Health $(\mathrm{NIH})$ Guide for the Care and Use of Laboratory Animals.

\section{Training protocol}

At the end of nine month, the mice were randomly assigned to control group ( $C G, n=10)$ or to the training group ( $T G, n=10)$. The animals from the TG were submitted to a treadmill running program. They were trained to run one hour a day for five days/week at $60 \%$ of the maximum effort test (MET) on the treadmill at 15\% gradient. The MET was performed at baseline on a treadmill at a speed of $0.3 \mathrm{Km} / \mathrm{h}$. Every five min the belt speed was increased in the same proportion $(0.3 \mathrm{~km} / \mathrm{h})^{8}$. The MET was performed every four weeks. After the first MET, the mice were subjected to eight weeks of treadmill training five days a week, with increasing velocity up to $60 \%$ of that achieved in the effort test. In the first week after the test, the animals ran for $30 \mathrm{~min}$, increasing this time by ten min each week until they reach $60 \mathrm{~min}$ in the fourth week, where at the end of it, another MET was performed to adjust the intensity of the training for the next four weeks.

All animals were adapted to the procedure (ten min/day; $0.3 \mathrm{~km} / \mathrm{h}$ ) for one-wk before beginning the training protocol. After the adaptation, the sedentary group was exposed to training only during the maximum treadmill test. However, they were placed on the stationary treadmill three times a week to provide a similar environment. Animals from the two groups were sacrificed at 11 months of age.

\section{Blood pressure measurements}

Systolic blood pressure was measured at two moments: at the beginning of the experiment and at the moment of sacrifice. The blood pressure was evaluated by indirect measurement using the tail-cuff method ${ }^{9}$.

\section{Determination of the number and sizes of NP granules and the relative volumes of the endoplasmic reticulum, mitochondria and Golgi complex}

The animals were euthanized with an intraperitoneal injection of sodium pentobarbital on overdose. Fragments of the right atrium were fixed in $2.5 \%$ glutaraldehyde in a phosphate buffer solution $(0.2 \mathrm{M}$, $\mathrm{pH}$ 7.3) for three hours. Then, they were washed with the same buffer solution for 15 minutes and placed in a solution of osmium tetroxide in 1\% phosphate buffer for two hours. The fragments remaining 12 hours in uranyl acetate $0.5 \%$ and were dehydrated in ascending series of alcohols and propylene oxide for eight hours under rotation. The fragments were included in pure resin for five hours and left on the same resin at $60^{\circ} \mathrm{C}$ for five days.

The ultrathin sections, obtained by an ultramicrotome (Sorvall MT-2) were contrasted with uranyl acetate and lead citrate and examined under a transmission electron microscope (Jeol, ICB, São Paulo University). Ten electron micrographs per animal obtained by systematic random sampling of quadrants examined with final magnification of x 15, 000 were used to obtain: the number of granules per $96 \mu \mathrm{m}^{2}$, the area of granules $\left(\mu \mathrm{m}^{2}\right)$ and the relative volume (\%) of endoplasmic reticulum, mitochondria and Golgi complex ${ }^{10-13}$ (Figure 1). The number of granules present in each field was determined and its area measured using an image analysis program (Axio Vision, Zeiss).

\section{Determination of the number of pores in the nuclear mem- brane and the relative volume of euchromatin}

Ten electron micrographs per mouse, examined with a final magnification of $x 15,000$, were used to determine the number of pores 
per $10 \mu \mathrm{m}$ of nuclear membrane and the relative volume of euchromatin in the cardiomyocyte nucleus.

\section{Calculation of the relative volumes}

The relative volume corresponds to the area occupied by the considered structure presented as a \%. It was obtained by using a test system consisting of 77 points that was superimposed on each electronic photomicrograph and the number of points that touched every component to be quantified was counted.

The relative volumes were calculated with the following formula:

$V_{V_{\text {[struct] }}}=\sum \mathrm{P}_{\text {[struct] }} .100 / P T$; being: $V V_{\text {[struct] }}=$ volume density; $\Sigma \mathrm{P}_{\text {[struct] }}=$ Number of points that hit the structure in question, and $\mathrm{PT}=$ Total number of points (77) of the test system ${ }^{13}$. The measurements was performed using an image analysis program (Axio Vision, Zeiss, 2009) obtained from the Laboratory of Quantitative Studies of Universidade São Judas Tadeu, São Paulo, Brazil.

\section{Statistical analysis}

The data obtained for each of the parameters were tabulated, the averages (mean \pm SD) calculated and constructed histograms of frequency distribution of the values of groups. The values of both groups were compared statistically by Student's $t$ test, with significance level of $p<0.05$. The GraphPad Prism 5 program (GraphPad Software, San Diego, (A, USA) for Windows was used for data analysis.

\section{RESULTS}

No significant difference was found in the mean systolic blood pressure between trained mice and control animals nor at the beginning $(113 \pm 2.9 \mathrm{mmHg}$ and $112 \pm 2.1 \mathrm{mmHg}$ ) nor at the end of the experiment $(111 \pm 2.3 \mathrm{mmHg}$ and $112 \pm 2.4 \mathrm{mmHg}$ and $113 \pm 2.4 \mathrm{mmHg}$ ) respectively for $C G$ and $T G$ animals (Table 1).

\section{Number and sizes of NP granules}

NP granules were predominantly arranged in groups among the mitochondria and near the Golgi complex and endoplasmic reticulum (Figure 2). The number of NP granules in the cytoplasm of the cardiomyocyte was greater in the TG mice compared with the CG mice $(p<0.05)$. Training also significantly increased the size of the NP granules $(p<0.05)$ (Figure 3).

\section{Relative volume of mitochondria, Golgi complex and endo- plasmic reticulum}

The mitochondria appeared mainly with vesicular form (Figure 2); the Golgi complex exhibited a number of vesicles and the endoplasmic reticulum appeared as widened cisternae localized among the secretory

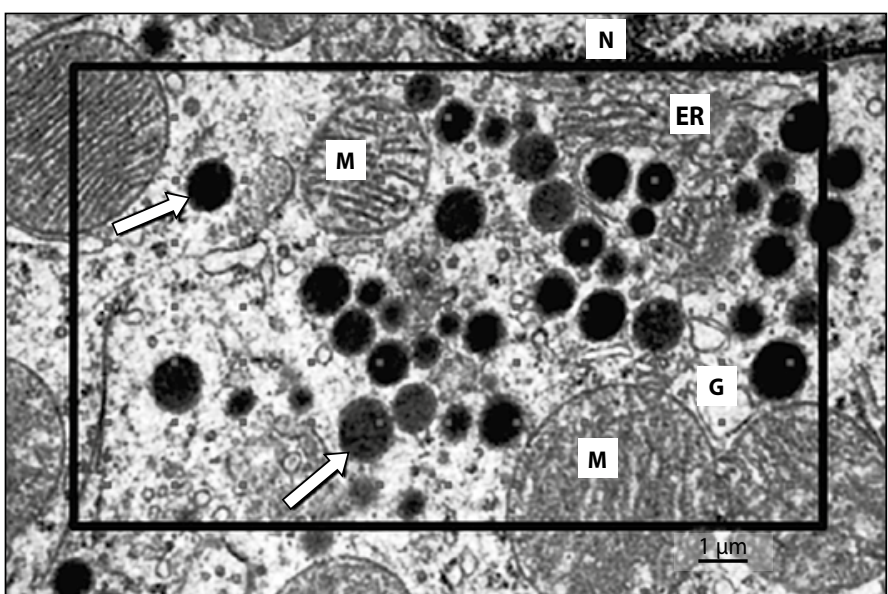

Figure 1. Electronic photomicrograph of a section of right atrial cardiomyocyte showing the cytoplasmic components to be quantified.

N: Nucleus; M: mitochondria; ER: endoplasmic reticulum; G: Golgi complex; Arrows: NP granules. granules (Figure 2). The TG mice showed higher relative volumes of the mitochondria, Golgi complex and endoplasmic reticulum, compared with the CG mice. In all cases, $\mathrm{p}<0.05$ (Table 1).

\section{Relative volume of euchromatin and number of pores in the nuclear membrane}

In the cardiomyocytes, the euchromatin appeared disperse whereas the heterochromatin appeared as a thin peripheral band adhered to the nuclear membrane (Figure 4). The nuclear membrane appears composed of two parallel membranes and the nuclear pores as electron dense structures embedded in spaces where the outer and inner nuclear membranes are joined to one another (Figure 4). The TG mice showed higher relative volumes of the euchromatin and of the number of pores per $10 \mu \mathrm{m}$ in the nuclear membrane, compared with the CG mice. In both cases, $p<0.05$.

Table 1. Morphometric indexes of the cardiomyocyte nucleus and cytoplasm in the right atrial cardiomyocytes of CG and TG mice.

\begin{tabular}{c|c|c|c}
\hline Morphometric indexes & CG & TG & p-value \\
\hline RVM (\%) & $16.4 \pm 0.20$ & $23.4 \pm 0.40^{*}$ & $<0.05$ \\
\hline RVGC (\%) & $2 \pm 0.1$ & $2.8 \pm 0.1^{*}$ & $<0.05$ \\
\hline RVER (\%) & $2.8 \pm 0.2$ & $3.4 \pm 0.1^{*}$ & $<0.05$ \\
\hline RVE (\%) & $66 \pm 5$ & $71 \pm 4.8^{*}$ & $<0.05$ \\
\hline $\mathrm{NPO} / 10 \mu \mathrm{m} \mathrm{NM}(\%)$ & $3.2 \pm 0.1$ & $4.1 \pm 0.3^{*}$ & $<0.05$ \\
\hline
\end{tabular}

RVM: relative volume of mitochondria; RVGC: relative volume of Golgi complex; RVER: relative volume of endoplasmic reticulum; RVE: relative volume of euchromatin; NPo/10 $\mu \mathrm{m}$ NM: number of pores/10 $\mu \mathrm{m}$ of nuclear membrane. ${ }^{*} \mathrm{p}<0.05$ vs. CG mice.
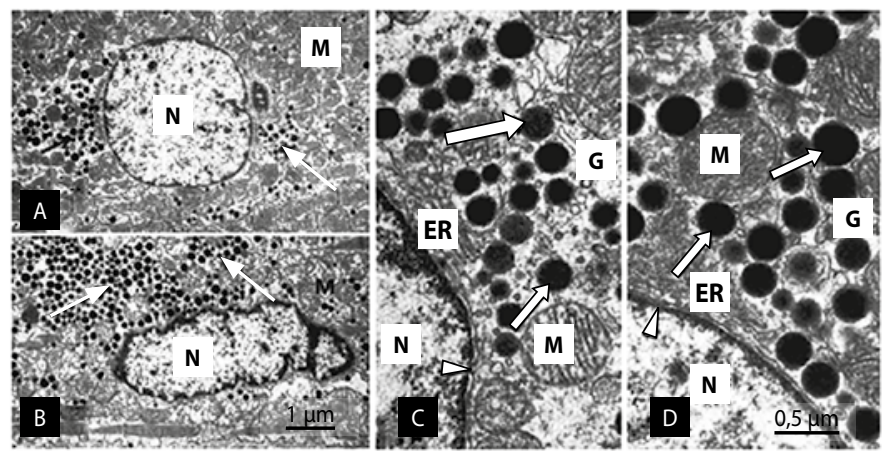

Figure 2. Electronic photomicrographs of sections obtained from right atrium cardiomyocytes from control group $(A, C)$ and trained group $(B, D)$. The number of NP-granules in $T G(B)$ is greater than CG (A). The sizes of the granules are larger in TG (D) than in CG (C). NP granules (white arrows).

M: Mitochondria;ER: Endoplasmic Reticulum;G: Golgi complex; N: Nucleus; Arrow heads: Nuclear pores.

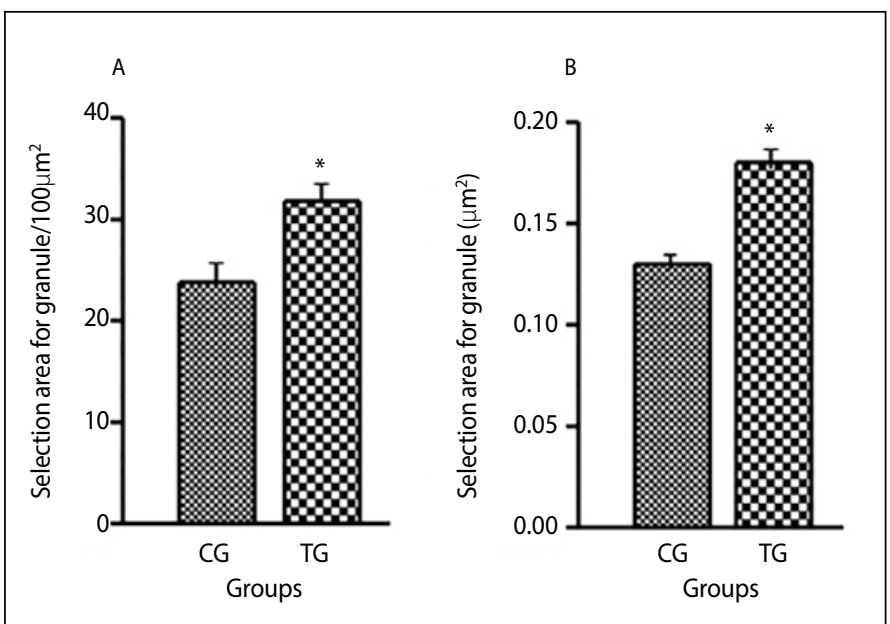

Figure 3. Mean data showing the effects of aerobic training on the number $(A)$ and size (B) of NP granules in right atrial cardiomyocytes.

${ }^{*} p<0.05$ vs. CG mice. 


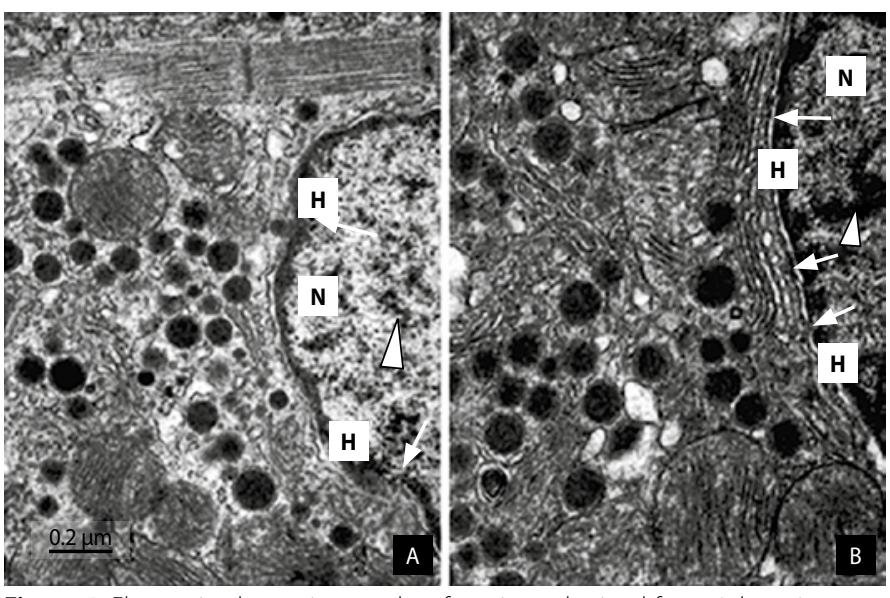

Figure 4. Electronic photomicrographs of sections obtained from right atrium cardiomyocytes from the CG $(A)$ and TG $(B)$ mice showing the nucleus $(N)$ with euchromatin (arrow heads) and the pores of nuclear membrane (arrows). Heterochromatin $(\mathrm{H})$ are also showed.

\section{DISCUSSION}

There are two main findings in the present work. First, mice subjected to aerobic training exhibited a significant increase in the number and sizes of NP granules from cardiomyocytes compared to sedentary animals, indicating that aerobic training activated the biosynthetic process in cardiomyocytes ${ }^{3}$. These data confirm previously results obtained by Barletta et al. ${ }^{5}$, Ohba et al. ${ }^{6}$, Edwards ${ }^{7}$ and Gutkowska et al. ${ }^{14}$. Second, the density of nuclear pores and the relative volumes for euchromatin, mitochondria, endoplasmic reticulum and of Golgi complex were significantly elevated in mice after eight-wk aerobic training. Thus, it was demonstrated the beneficial effects induced by aerobic training on the components from the secretory apparatus of cardiomyocyte. These findings are consistent with that of an early research, indicating that the production and secretion of NPs depend on the secretory apparatus activity of atrial cardiomyocytes ${ }^{3}$.

Aerobic training produces substances that acts on cardiomyocytes upon binding to intracellular and membrane receptors which existence has been demonstrated in cardiomyocytes ${ }^{15}$. Substance binding cause conformational changes to receptors with attachment to cellular proteins serving the transcriptional coactivators. Studies in rats have demonstrated that exercise could increase atrial substances receptors and NPs transcription ${ }^{16}$. It is possible that this is the case of the present results. The increased euchromatin volumetric fraction in the training mice and subsequent rise of RNA transcription rates associated with the increased volume in the Golgi complex provide evidence that the rate of NP synthesis may increase as a response to the stimulation by aerobic training, as also observed in skeletal muscle by Malysz et al. ${ }^{17}$.

The present study suggests that aerobic training can act as an effective treatment to enhance mitochondrial adaptations in atrium muscle. This is consistent with the finding ${ }^{18}$ that aerobic training elicits beneficial changes in mitochondria that may protect cells against the effects of aging.

The right atrium produces two forms of NPs (ANP and BNP) having with main function acute control of BP through vasodilation and release of water and sodium of the blood vessels throughout NP Receptor-A (NPR-A) interaction ${ }^{19}$. The activation of these receptors leads to a reduction in preload by the elimination of water and sodium and by shifting plasma volume from intravascular to extravascular spaces ${ }^{20}$.

The natriuretic and diuretic actions of NPR-A result from enhanced glomerular filtration and/or decreased tubular reabsorption of sodium and water, suppression of renin, aldosterone, and vasopressin secretion as well as antagonism of most of the peripheral and central effects of angiotensin $1{ }^{19,21}$. If the chronic training promotes a parallel increase of NPRs and NPs, then this also explains the concomitant increased production of $\mathrm{NO}$ and NPs ${ }^{22}$, observed by Gutkowska et al. ${ }^{14}$

Several studies have demonstrated that training stimulated the synthesis and release of the vasodilator/antiproliferative factor NO via both a genomic and non-genomic mechanism acting at the level of $\mathrm{NO}$ synthase ${ }^{23}$. It has also been postulated that the action of the NO system and its synthesis suffer significant control of NPs ${ }^{22}$. Interestingly, elite athletes (which have high production endogenous $\mathrm{NO}$ ) do not get ergogenic effects of nitrate supplementation ${ }^{24}$, as opposed to sedentary individuals ${ }^{25}$. This probably occurs because elite athletes already have a machinery able to fulfill the physiological needs of NO to a maximum aerobic performance (dependent on the NO system). So, in elite athletes, the non-ergogenic response of nitrate supplementation might be related to NPs activity and its secretory apparatus.

Studies have shown that aerobic training promotes beneficial effects on cardiac remodeling ${ }^{26}$ and pathological hypertrophy ${ }^{27}$. A sustained increase in systolic load, as observed in systemic hypertension leads to a concentric pattern of cardiac hypertrophy, characterized by the increased expression of the putative hypertrophic marker prepro-ANP mRNA ${ }^{28-30}$ However, in the present study we did not use hypertensive animals in training suggesting the absence of the cardiac hypertrophic response. To further confirm this latter premise, it would be needed to examine left ventricular prepro-ANP mRNA expression. In this case the steady-state mRNA level of prepro-ANP would be unchanged in the RA cardomyocytes of the training mice, as compared to sedentary animals.

\section{CONCLUSION}

The results of the present study indicate that in mice with normal arterial pressure, aerobic training is accompanied by hypertrophy of nuclear and cytoplasmic components related to the production and secretion of NPS.

\section{ACKNOWLEDGEMENTS}

The authors were funded by Universidade São Judas, São Paulo, Coordenação de Aperfeiçoamento de Pessoal de Nível Superior and Fundação de Amparo à Pesquisa do Estado de São Paulo during this Project.

All authors have declared there is not any potential conflct of interests concerning this article.

AUTHORS' CONTRIBUTIONS: Each author contributed individually and significantly to the development of this study. RRS (0000-0002-3251-276X) * VGCO and TCPC were the main contributors in the drafting of the manuscript. LBMM performed the training of animals and gathered data; EF and RRS, performed the statistical analysis, the literature search and review of the manuscript. *ORCID (Open Researcher and Contributor ID).

\section{REFERENCES}

1. Daniels LB, Maisel AS. Natriuretic peptides. J Am Coll Cardiol. 2007;50(25):2357-68.

2. O'Donnell PJ, Driscoll WJ, Bäck N, Muth E, Mueller GP. Peptidylglycine-a-amidating monooxygenase and pro-atrial natriuretic peptide constitute the major membrane-associated proteins of rat atrial secretory granules. J Mol Cell Cardiol. 2003;35(8):915-22.

3. MaksimovVF, Korostyshevskaya IM, Markel'AL, Shmerling MD, Yakobson GS. Structural characteristics of cardiomyocytes in the right atrium of NISAG rats. Bull Exp Biol Med. 2004;138(1):1-4.
4. Brum PC, Forjaz CLM, Tinucci T, Negrão CE. Adaptações agudas e crônicas do exercício físico no sistema cardiovascular. Rev Paul Educ Fís. 2004;18:21-31.

5. Barletta G, Stefani L, Del Bene R, Fronzaroli C, Vecchiarino S, Lazzeri C, et al. Effects of exercise on natriuretic peptides and cardiac function in man. Int J Cardiol. 1998;65(3):217-25.

6. Ohba H, Takada H, Musha H, Nagashima J, Mori N, Awaya T, et al. Effects of prolonged strenuous exercise on plasma levels of atrial natriuretic peptide and brain natriuretic peptide in healthy men. Am Heart 
J. 2001;141(5):751-8.

7. Edwards JG. Swim training increases ventricular atrial natriuretic factor (ANF) gene expression as an early adaptation to chronic exercise. Life Sci. 2002;70(23):2753-68.

8. Fontinele RG, Mariotti VB, Vazzoler AM, Ferrão JSP, Kfoury Jr JR, De Souza RR. Menopause, exercise, and knee. What happens? Microsc Res Tech. 2013;76(4):381-7.

9. Britto RR, Santos RAS, Fagundes-Moura CR, Khosla MC, Campagnole-Santos MJ. Role of angiotensin-(1-7) in the modulation of the baroreflex in renovascular hypertensive rats. Hypertension. 1997;30(3):549-56.

10. Souza RR, Oliveira VC, Curi TC, Maldonado DC. Effects of ovariectomy on the secretory apparatus in the right atrial cardiomyocytes of middle-aged mice. Clinics (Sao Paulo). 2014;69(8):554-8.

11. Gama EF, Liberti EA, de Souza RR. Effects of pre-and postnatal protein deprivation on atrial natriuretic peptide-(ANP-) granules of the right auricular cardiocytes. An ultrastructural morphometric study. Eur J Nutr. 2007:46(5):245-50.

12. Gama EF, de Carvalho CAF, Liberti EA, de Souza RR. Atrial natriuretic peptide (ANP)-granules in the guinea pig atrial and auricular cardiocytes: an immunocytochemical and ultrastructural morphometric comparative study. Ann Anat. 2007;189(5):457-64.

13. Gundersen HJ, Bendtsen TF, Korbo L, Marcussen N, Møller A, Nielsen K, et al. Some new, simple and efficient stereological methods and their use in pathological research and diagnosis. APMIS. 1988;96(5):379-94.

14. Gutkowska J, Paquette A, Wang D, Lavoie JM, Jankowski M. Effect of exercise training on cardiac oxytocin and natriuretic peptide systems in ovariectomized rats. Am J Physiol Regul Integr Comp Physiol. 2007;293(1):R267-75.

15. Holtwick R, van Eickels M, Skryabin BV, Baba HA, Bubikat A, Begrow F, et al. Pressure-independent cardiac hypertrophy in mice with cardiomyocyte-restricted inactivation of the atrial natriuretic peptide receptor guanylyl cyclase-A. J Clin Invest. 2003;111(9):1399-407.

16. Shanshan P, Yan Z, Aiyun L, Chen P. Effect of exercise on gene expression of atrial natriuretic peptide receptor of kidney. Life Sci. 2005;76(17):1921-8.

17. Malysz T, Ilha J, Severo do Nascimento P, Faccioni Heuser MC, De Angelis K, D'agord Schaan B, et al. Exercise training improves the soleus muscle morphology in experimental diabetic nerve regeneration. Muscle Nerve. 2011;44(4):571-82
18. Joseph AM, Nguyen LMD, Welter AE, Dominguez JM II, Behnke BJ, Adhihetty PJ. Mitochondrial adaptations evoked with exercise are associated with a reduction in age-induced testicular atrophy in Fischer-344 rats. Biogerontology. 2014;15(5):517-34.

19. Potter LR, Yoder AR, Flora DR, Antos LK, Dickey DM. Natriuretic peptides: their structures, receptors, physiologic functions and therapeutic applications. Handb Exp Pharmacol. 2009;(191):341-66.

20. Potter LR, Abbey-Hosch S, Dickey DM. Natriuretic peptides, their receptors, and cyclic guanosine monophosphate-dependent signaling functions. Endocr Rev. 2006;27(1):47-72.

21. Hong M, Yan Q, Tao B, Boersma A, Han K-K, Vantyghem MC, et al. Estradiol, progesterone and testosterone exposures affect the atrial natriuretic peptide gene expression in vivo in rats. Biol Chem Hoppe Seyler. 1992;373(1):213-8.

22. Costa MA, Arranz CT. New aspects of the interactions between the cardiovascular nitric oxide system and natriuretic peptides. Biochem Biophys Res Commun. 2011;406(2):161-4.

23. Nishikimi T, Maeda N, Matsuoka H. The role of natriuretic peptides in cardioprotection. Cardiovasc Res 2006;69(2):318-28.

24. Jonvik KL, Nyakayiru J, van Loon LJ,Verdijk LB. Can elite athletes benefit from dietary nitrate supplementation? J Appl Physiol. 2015;119(6):759-61.

25. Porcelli S, Ramaglia M, Bellistri G, Pavei G, Pugliese L, Montorsi M, et al. Aerobic fitness affects the exercise performance responses to nitrate supplementation. Med Sci Sports Exerc. 2015;47(8):1643-51.

26. Haykowsky MJ, Liang Y, Pechter D, Jones LW, McAlister FA, Clark AM. A meta-analysis of the effect of exercise training on left ventricular remodeling in heart failure patients: the benefit depends on the type of training performed. J Am Coll Cardiol. 2007;49(24):2329-36.

27. Yang L, Jia Z, Yang L, Zhu M, Zhang J, Liu J, et al. Exercise protects against chronic $\beta$-adrenergic remodeling of the heart by activation of endothelial nitric oxide synthase. PLoS One. 2014;9(5):e96892.

28. Grossman W, Jones D, McLaurin LP. Wall stress and patterns of hypertrophy in the human left ventricle. J Clin Invest. 1975;56(1):56-64.

29. Weber K, Brilla CG. Pathological hypertrophy and cardiac interstitium. Fibrosis and renin-angiotensin-aldosterone system. Circulation. 1991;83(6):1849-65.

30. Weber KT. The lonely failing heart: a case for ECM genes. Cardiovasc Res. 1995;30(6):835. 